\title{
Mengapa Kepercayaan Diri Mempengaruhi Kemampuan Menulis Kreatif Siswa?
}

\author{
Himan Muttaqin Gunawan \\ muttaqinhilman19@gmail.com
}

\author{
Rahmat Aziz \\ azira@uin-malang.ac.id
}

Fakultas Psikologi, Universitas Islam Negeri (UIN) Maulana Malik Ibrahim Malang, Indonesia

\begin{abstract}
Abstrak
Penelitian ini bertujuan untuk menguji hubungan antara kepercayaan diri dengan kemampuan menulis kreatif siswa. Jumlah sampel pada penelitian ini berjumlah 73 siswa Madrasah Aliiyah Negeri 2 Bogor. Metode pengumpulan data adalah skala kepercayaan diri, sementara metode pengumpulan data yang digunakan untuk variabel kemampuan menulis kreatif menggunakan tes menulis kreatif. Hasil analisis menunjukan adanya hubungan positif antara kepercayaan diri dengan kemampuan menulis kreatif, semakin tinggi tingkat kepercayaan diri maka semakin tinggi pula tingkat kemampuan menulis kreatif. Variabel kepercayaan diri mampu menjadi prediktor bagi tinggi rendahnya kemampuan menulis kreatif sebesar $6,1 \%$.
\end{abstract}

Keywords: Kepercayaan diri; menulis kreatif; siswa

Psikoislamika : Jurnal Psikologi dan Psikologi Islam (JPPI) Volume 15. Nomor 2, Tahun 2018. copyright (C) 2018. Pusat Penelitian dan Layanan Psikologi.

\section{PENDAHULUAN}

Kecerdasan linguistik atau disebut juga kecerdasan bahasa adalah salah satu kecerdasan yang termasuk ke dalam Multiple Intelegence. Kecerdasan linguistik adalah kecerdasan yang terkait dengan kemampuan menulis, membaca, dan berkomunikasi dengan kata-kata atau Bahasa (Abidin, 2010:7). Menulis secara garis besar terbagi kedalam dua jenis yaitu menulis akademik (academic writing) dan menulis kreatif (Aziz, 2018).

Zainurrahman (2011:162) menyatakan berdasarkan namanya, tulisan akademik adalah tulisan yang digunakan dalam lingkungan akademik; seperti laporan penelitian, makalah, artikel, atau jurnal-jurnal ilmiah. Perbedaan umum antara tulisan akademik dan nonakademik adalah lingkungan dimana tulisan tersebut diciptakan dan digunakan. Tulisan akademik ditulis oleh komponen masyarakat akademik (misalnya sebuah universitas) untuk digunakan dalam proses belajar mengajar, penelitian, atau untuk dipublikasikan sebagai artikel ilmiah. Tulisan akademik bersifat ilmiah, baik yang berbasis penelitian maupun esai yang tidak berbasis penelitian.

Pengertian kemampuan menulis kreatif merujuk pada pendapat Yunus (2015) yang mendefinisikan bahwa menulis kreatif berasal dari dua kata yaitu menulis dan kreatif. Menulis merupakan kemampuan untuk menuangkan idide dan gagasan secara tertulis, sedangkan kreatif merupakan kemampuan untuk menciptakan sesuatu. Menulis kreatif merupakan suatu proses yang bertumpu pada pengembangan daya cipta dan ekspresi pribadi dalam bentuk tulisan yang baik dan menarik. Artinya, menulis kreatif menekankan pada proses aktif seseorang untuk menuangkan ide dan gagasan melalui cara yang tidak biasa sehingga menghasilkan karya cipta yang berbeda, tidak hanya baik, tapi juga menarik. 
Salah satu kegiatan menulis yang dapat memberikan banyak manfaat adalah menulis kreatif. Terdapat beberapa penelitian yang menyebutkan bahwa dengan menulis kreatif akan banyak manfaat positif yang didapatkan oleh pribadi kita sendiri, salah satunya adalah yang dilakukan oleh Psychol (2010) yang menyatakan seseorang yang sering melakukan kegiatan menulis kreatif cenderung bisa menurunkan tingkat stresnya. Contoh lain adalah penelitian yang dilakukan oleh Damianakis (2001) yang menyatakan bahwa menulis kreatif dalam bentuk satu cerita bisa menjadi sarana penting untuk merekonstruksi kehidupan seseorang.

Pentingnya kegiatan menulis kreatif pada siswa ternyata tidak berjalan lurus dengan fasilitas penunjang serta dukungan dari berbagai pihak dalam pendidikan di Indonesia. Salah satu contohnya adalah pembelajaran menulis cerita pendek alias cerpen yang merupakan salah satu bagian dari kegiatan menulis kreatif. Berdasarkan hasil wawancara pribadi dengan salah satu Guru Bahasa Indonesia di tempat penelitian ini dilaksanakan, penulis menyimpulkan bahwa terdapat beberapa unsur masalah yang menjadi penghalang pembelajaran tersebut, yaitu 1) rendahnya kompetensi guru dalam menulis cerpen serta kompetensi guru dalam membimbing siswa nya menulis cerpen, serta 2) kegiatan menulis cerpen hanya dimuat sebagai kompetensi dasar (KD) di dalam rancangan pembelajaran.

Selain faktor fasilitas penunjang dalam ranah pendidikan, karakteristik kepribadian dan kemampuan berpikir kreatif juga memengaruhi kemampuan menulis kreatif seseorang. Aziz (2009) dalam penelitiannya mengenai pribadi kreatif dan menulis kreatif menyatakan bahwa kemampuan berfikir kreatif memengaruhi kemampuan menulis kreatif, kedua hal tersebut tidak dapat dipisahkan dan saling berkaitan terdapat hubungan antara kepribadian kreatif dengan menulis kreatif.

Pada penelitian yang sama, Aziz (2018) menyatakan bahwa terdapat hubungan antara kepribadian kreatif dengan menulis kreatif. Adapun salah satu karakteristik dalam kepribadian kreatif adalah kepercayaan diri, Lopez (2003) menyatakan tentang karakteristik kepribadian kreatif menemukan bahwa kepercayaan diri yang merupakan salah satu karakteristik pribadi kreatif memengaruhi creative performance seseorang. Kemudian penelitian yang dilakukan oleh Mubarok (2016) menyatakan bahwa tingkat kepercayaan diri seseorang memengaruhi tingkat kreativitas yang di ukur menggunakan tes kreativitas verbal.

Berdasarkan beberapa penelitian diatas, peneliti berasumsi bahwa terdapat hubungan positif antara kepercayaan diri dengan kemampuan menulis kreatif. Hal ini didasarkan pada, a) orang yang percaya diri memiliki keyakinan akan kemampuan dirinya sehingga ia akan bersungguh-sungguh akan apa yang dilakukannya bahkan dalam menulis kreatif sekalipun, b) orang yang percaya diri selalu optimis sehingga dalam melakukan suatu hal ia akan selalu bepikiran positif bahwa apa yang dilakukannya mampu diselesaikan dengan baik, c) orang yang percaya diri selalu bertanggung jawab atas apa yang dilakukannya, ia mampu keluar dari "zona nyaman" dan "out of the box" tanpa takut dengan kritikan orang lain namun tetap siap menanggung segala konsekuensi yang akan diterimanya.

\section{METODE PENELITIAN}

Rancangan dalam penelitian ini adalah menggunakan pendekatan kuantitatif. Kuantitatif adalah penelitian yang banyak disajikan berupa angka-angka. Hal ini sesuai dengan pendapat Arikunto (1998) yang mengemukakan "penelitian kuantitatif adalah pendekatan penelitian yang banyak dituntut menguatkan angka, mulai dari pengumpulan data, penafsiran terhadap data tersebut, serta penampilan hasilnya".

Pendapat lainnya dikemukakan Azwar (2007) menyatakan bahwa "penelitian kuantitatif menekankan analisisnya pada data-data numerical (angka) yang diolah dengan metode statistika". Pada dasarnya, pendekatan kuantitatif dilakukan pada penelitian inferensial (dalam rangka pengujian hipotesis). Dengan metode kuantitatif akan diperoleh signifikasi perbedaan kelompok atau signifikasi hubungan antar variabel yang diteliti. Jenis dari penelitian ini adalah kuantitatif korelasional yang bertujuan untuk mengetahui hubungan Antara variabel bebas dengan variabel terikat. Disain yang akan digunakan pada penelitian ini adalah disain cross-sectional study, yang berarti penelitian ini dilakukan dengan mengumpulkan informasi hanya dalam satu waktu dan tidak berkelanjutan. 
Selanjutnya perlu dijelaskan definisi operasional sebagai berikut:

1.Kemampuan menulis kreatif merupakan kemampuan seseorang dalam menuangkan ide, gagasan, pemikiran, ataupun perasaan namun yang bersifat kreatif, bukan tulisan dalam bentuk akademik yang mengharuskan dilakukan dengan teliti dan saintifik, dalam artian bahwa tulisan yang diciptakan merupakan sebuah karya baru diluar konteks akademik.

2. Kepercayaan diri merupakan keyakinan seseorang untuk percaya pada diri nya sendiri bahwa dirinya mampu untuk menyelesaikan berbagai masalah yang dihadapi, mampu bersikap mandiri, serta tidak terlalu mengkhawatirkan mengenai masa depan yang akan datang baik dalam konteks pendidikan, maupun kehidupan sosial nya secara luas.

Penelitian ini dilaksanakan di Madrasah Aliyah Negeri (MAN) 2 Bogor yang merupakan salah satu sekolah lanjutan tingkat atas di Kota Bogor. Status social siswa nya sebagian besar pada kategori menengah, namun terdapat pula sebagian kecil yang berada pada kategori menengah atas maupun menengah bawah. Jumlah subjek pada penelitian ini sebanyak 73 siswa. Pada awalnya jumlah subjek penelitian sebanyak 75 siswa, namun di hari kedua pengambilan data dua orang siswa tidak hadir sehingga tidak disertakan dalam analisis data. Dari total 73 subjek tersebut sebanyak 43 subjek berjenis kelamin perempuan dan sisanya sebanyak 30 subjek berjenis kelamin laki-laki.

Kepercayaan Diri diukur menggunakan skala piskologis yang disusun penulis berdasarkan indikator dan aspek-aspek kepercayaan diri yang dikembangkan oleh Lauster (dalam Ghufron \& Risnawita, 2010). Bentuk skala yang digunakan adalah skala Likert, dimana skala ini digolongkan skala untuk orang dan rancangan yang pada dasarnya disusun untuk mengukur sikap. Dalam kategori penilaian pendukung (favorable), yaitu sangat setuju $(\mathrm{SS})=4$, setuju $(\mathrm{S})=3$, tidak setuju $(\mathrm{TS})=2$, dan sangat tidak setuju $(\mathrm{STS})=1$. Sementara dalam kategori penilaian tidak mendukung (unvaforable) yaitu sangat setuju (SS) $=1$, setuju $(S)=2$, tidak setuju (TS), dan sangat tidak setuju $(\mathrm{STS})=4$.

Kemampuan Menulis Kreatif diukur melalui tes menulis cerita pendek yang hasilnya dinilai oleh peneliti dan Guru Bahasa Indonesia berdasarkan Model Penilaian Kreativitas dalam Mengarang yang dikembangkan oleh Munandar (2002). Skema penilaian tersebut meliputi empat kriteria dari berpikit kreatif, yaitu kelancaran (fluency), kelenturan (flexibility), keaslian (originality), dan keterperincian (elaboration). Setiap kriteria terdiri dari lima komponen, sehingga ada 20 butir komponen yang dinilai. Untuk setiap butir yang memenuhi syarat diberi skor 1 kecuali pada kriteria Kelancaran, pada kriteria ini jika karangan tersebut dinilai Sangat Lancar maka diberi skor 5, jika Lancar diberi skor 4, jika Cukup Lancar diberi skor 3, jika Kurang Lancar diberi skor 2, dan jika Tidak Lancar diberi skor 1, sehingga skor maksimal yang dapat diperoleh adalah 20.

Kelancaran dalam mengemukakan gagasan dinilai dari jumlah gagasan yang muncul dalam karangan tersebut. Kelenturan meliputi kelenturan dalam struktur kalimat dan kelenturan dalam isi atau gagasan. Keaslian dinilai melaui sejauh mana isi atau gaya pemikiran karangan menunjukan orisinalitas dibandingkan dengan karangan yang isi dan gaya penulisannya menunjukan stereotip. Keterperincian adalah kemampuan untuk membumbui atau menghiasi cerita, sehingga nampak lebih kaya (Munandar, 2002:65-66).

Analisis yang digunakan dalam penelitian ini meliputi uji korelasi product moment dan uji regresi sederhana secara linear. Uji korelasi digunakan untuk menganalisis hubungan antara kepercayaan diri dan menulis kreatif, sementara uji regresi digunakan untuk mengidentifikasi pengaruh kepercayaan diri terhadap kemampuan menulis kreatif.

\section{HASIL PENELITIAN}

Hasil uji normalitas menghasilkan probabilitas (p) data kepercayaan diri sebesar 0,250 ( $>$ > 0,05) dan probabilitas ( $p$ ) data kemampuan menulis kreatif sebesar 0,123 (p> $0,05)$. Hal ini menunjukkan bahwa distribusi data pada kedua sampel adalah normal.

Perbandingan antara mean hipotetis dengan mean empiris, Ferguson (dalam Aziz, 2009:121) menyatakan bahwa harga mean hipotesis dapat dapat dianggap sebagai mean populasi $(\mu)$ yang diartikan sebagai kategori sedang suatu kelompok subjek pada variabel yang diteliti. Setiap skor mean empiris $(M)$ yang lebih tinggi dari mean populasi $(\mu)$ dapat dianggap sebagai 
indikator tingginya kelompok subjek pada variabel yang diteliti. Sebaliknya setiap skor mean empiris yang lebih rendah secara signifikan dari mean populasi $(\mu)$ dapat dianggap sebagai indikator rendahnya keadaan kelompok subjek yang diteliti.

Perbandingan antara mean hipotesis dengan mean empiris dapat disimpulkan bahwa:

1. Mean empiris kepercayaan diri yang diperoleh subjek lebih tinggi dibanding mean hipotesis nya (79.2:65) yang artinya tingkat kepercayan diri subjek berada pada kategori tinggi. Standar deviasi empiris yang diperoleh subjek lebih rendah dibanding standar deviasi hipotesisnya (6.5:13), artinya tingkat kepercayaan diri subjek memiliki variasi yang rendah atau cenderung sama/seragam.

2. Mean empiris kemampuan menulis kreatif yang diperoleh subjek sedikit lebih tinggi dibanding mean hipotesis nya (10.70:10) yang artinya tingkat kemampuan menulis kreatif siswa kelas XI MAN 2 Bogor berada pada kategori tinggi. Standar deviasi empiris yang diperoleh subjek lebih tinggi dibanding standar deviasi hipotesisnya (4.15:3.16), artinya tingkat kemampuan menulis kreatif siswa kelas XI MAN 2 Bogor memiliki variasi yang tinggi/berbeda-beda atau dapat dikatakan bahwa ada siswa yang memiliki kemampuan menulis kreatif yang tinggi, dan ada pula yang sedang, serta rendah.

Berdasarkan hasil analisis korelasi product moment antara variabel kepercayaan diri dengan variabel kemampuan menulis kreatif, diperoleh nilai pearson correlation $(R=0,272)$ dengan sig $(\mathrm{p})=(0,020)$, yang artinya $(\mathrm{p})<0,05$. Hasil penelitian tersebut menunjukan adanya korelasi positif yang signifikan antara variabel kepercayaan diri dengan kemampuan menulis kreatif pada siswa kelas XI MAN 2 Bogor. Analisis regresi linear variabel kepercayaan diri dengan kemampuan menulis kreatif menunjukan nilai $R=0,272$ dengan koefisien determinan sebesar 0,074. Namun setelah dilakukan penyesuaian koefisien korelasinya ( $R$ adjusted) berubah menjadi 0,061 . Hal ini berarti bahwa kepercayaan diri mampu menjadi prediktor bagi tinggi rendahnya kemampuan menulis kreatif sebesar $6,1 \%$.

Semakin tinggi kepercayaan diri maka semakin tinggi pula kemampuan menulis kreatif siswa kelas XI MAN 2 Bogor. Hasil penelitian terdahulu yang menunjukan adanya hubungan positif antara kepercayaan diri dengan kemampuan menulis kreatif dapat dilihat pada penelitian yang dilakukan oleh Aziz (2009). Sebuah studi tentang karakteristik pribadi kreatif dan kemampuan menulis kreatif pada siswa menunjukan bahwa sikap kreatif (dengan kepercayaan diri sebagai salah satu cirinya) memiliki hubungan sebesar $r=.318$ dengan nilai $p=0,014$. Lebih jauh, penelitian yang dilakukan oleh Lopez (2003) studi mengenai hubungan antara kepercayaan diri dengan creative performance pada dunia kerja menunjukan hasil bahwa terdapat hubungan positif diantara kedua variabel tersebut. Dengan korelasi sebesar 0,560 kepercayaan diri menjadi prediktor sebesar $31,4 \%$ bagi creative performance seseorang, dengan hasil tersebut Lopez menarik kesimpulan apabila kita menginginkan seseorang yang memiliki tingkat creative performance yang tinggi maka carilah seseorang dengan tingkat kepercayaan diri yang tinggi. Pernyataan tersebut secara tidak langsung menunjukan bahwa terdapat hubungan positif antara kepercayaan diri dengan creative performance seseorang.

Hasil penelitian ini juga sejalan dengan penelitian yang dilakukan oleh Mubarok (2016) tentang hubungan antara kepercayaan diri dengan kreativitas siswa yang diukur menggunakan tes kreativitas verbal. Dalam penelitian tersebut variabel kepercayaan diri memiliki hubungan dengan tingkat kreativitas dengan $r=.398$ dan nilai $p=0.000$. Terdapat kesamaan antara tes menulis kreatif dengan tes kreativitas verbal, keduanya sama-sama mengukur aspek kelancaran (fluency), fleksibilitas (flexibility), orisinalitas (originality), dan elaborasi (elaboration), perbedaannya adalah pada output tes dimana tes menulis kreatif berupa tulisan sedangkan tes kreativitas verbal berupa lisan.

\section{KESIMPULAN DAN SARAN}

Menulis kreatif merupakan suatu kegiatan yang banyak memberikan dampak positif bagi penulisnya, memiliki kemampuan menulis kreatif yang rendah bukan berarti tidak ada dampak positif dari kegiatan tersebut. Mengembangkan kemampuan menulis kreatif dapat dilakukan pada kegiatan-kegiatan di sekolah, mengajak lebih giat siswa nya untuk menulis dan membaca merupakan salah satu 
upaya yang paling mudah untuk meningkatkan minat menulis para siswa, selain itu pengadaan pelatihan mengenai menulis kreatif melalui ekstrakurikuler yang berkaitan juga sangat baik untuk dilakukan.

Meskipun berdasarkan hasil penelitian siswa kelas XI MAN 2 Bogor berada pada kategori kepercayaan diri yang tinggi, namun upaya untuk terus meningkatkan kepercayaan diri siswa perlu untuk terus dilakukan, terlebih ketika mereka beranjak ke kelas XII dan akan menghadapi ujian akhir. Upaya meningkatkan kepercayaan diri tidak selalu membutuhkan proses yang sulit dan panjang, selalu memberi support serta memuji/menghargai apa yang telah dilakukan para siswa adalah salah satu cara paling sederhana untuk meningkatkan rasa percaya diri siswa.

Selalu berpandangan positif mengenai diri sendiri adalah cara terbaik untuk menjalani kehidupan baik di sekolah maupun masyarakat luas. Rasa percaya diri tidak hadir dengan sendirinya, lakukanlah hal-hal yang mampu membuat rasa percaya diri kita meningkat namun tidak kelewat batas. Memiliki kemampuan menulis kreatif yang rendah bukan berarti tidak bisa meningkatkannya, ingatlah bahwa practice make perfect maka dari itu teruslah untuk menulis karna disadari secara langsung atau tidak, akan banyak manfaat positif yang bisa didapatkan melalui menulis

Bagi penelitian selanjutnya, lebih berhatihati dalam pelaksanaan pengambilan data terutama variable kemampuan menulis kreatif. Hindari hal-hal yang dapat menjadi variabel pengganggu dalam pengambilan data kemampuan menulis kreatif, contohnya adalah hindari waktu saat para siswa sedang istirahat, di akhir jam kepulangan sekolah, dan semua kondisi yang mengindikasikan bahwa siswa tidak akan mau mengerjakan tes tersebut secara $100 \%$ dengan potensi yang dimilikinya.

\section{DAFTAR PUTAKA}

Abidin, M. (2010). Menjadi Kreatif dengan Menulis. Malang: UIN Maliki Press

Arikunto, S. (1998). Prosedur Penelitian, Suatu Pendekatan Praktek (Edisi ke IV). Jakarta: PT Rineka Cipta

Aziz, R., (2018), Creative Learning: Teori, Praktik dan Riset, Malang: Edulitera
Azwar, S. (2007). Penyusunan Skala Psikologi. Yogyakarta: Pustaka Pelajar

Gufron, N. \& Risnawita, R. (2012). Teori-teori Psikologi. Cetakan Ketiga. Jogjakarta: Ar-Ruzz Media

Damianakis, T. (2001). Postmodernism, Spirituality, and The Creative Writing Process: Implications for Social Work Practice. Families in Society: The Journal of Contemporary Human Service, 82 (1), 23

Lopez, N. R. (2003). An Interactional Approach to Investigating Individual Creative performance. Thesis, The faculty of the Department of Psychology San Jose State University

Mubarok, M. H. (2016). Hubungan Kepercayaan Diri dengan Kreativitas Pada Siswa Kelas VIII SMPN 10 Malang. Skripsi. Fakultas Psikologi UIN Maulana Malik Ibrahim Malang

Munandar, S. C. U. (2002). Kreativitas dan Keberbakatan: strategi mewujudkan potensi kreatif dan bakat. Cetakan kedua. Jakarta: Gramedia

Psychol, J. C. (2010). Effect of Assertiveness Training and Expressive Writing on Acculturative Stress in International Student: A Randomized Trial. National Institute of Health, 56(4), 590-596 Yunus, S. (2015). Kompetensi Menulis Kreatif. Jakarta: Ghalia Indonesia

Zainurrahman. (2011). Menulis: Dari Teori Hingga Praktik (Penawar Racun Plagiarisme). Bandung: Alfabeta 